\title{
Requiem for a neurologist: the funeral rites of Jean-Martin Charcot
}

\author{
Réquiem para um neurologista: os ritos do funeral de Jean-Martin Charcot \\ Hélio Afonso Ghizoni Teive', Paula Marques', Francisco Manoel Branco Germiniani', Olivier Walusinski²
}

\begin{abstract}
Jean-Martin Charcot, the founder of modern neurology and leading figure in international neurology in the $19^{\text {th }}$ century, died on August 16 , 1893, in the province of Morvan in the French countryside, at the age of 67. The funeral service was held in Paris at the La Salpêtrière Hospital, and Charcot was buried in Montmartre cemetery in the same city.
\end{abstract}

Keywords: neurology; Jean-Martin Charcot, history

RESUMO

Jean-Martin Charcot, o fundador da moderna neurologia e figura exponencial da neurologia mundial no século XIX, faleceu no dia 16 de agosto de 1893, na província de Morvan, no interior da França, aos 67 anos de idade. 0 serviço funerário foi realizado em Paris, no hospital de La Salpêtrière e o enterro ocorreu no cemitério Montmartre, também em Paris.

Palavras-chave: neurologia; Jean-Martin Charcot, história

Jean-Martin Charcot (1825-1893) is considered the father of modern neurology and one of the most important physicians and medical researchers of the $19^{\text {th }}$ century $y^{1,2}$. His tremendous contributions to science extended beyond neurology, a field in which he described countless diseases, such as amyotrophic lateral sclerosis, multiple sclerosis, Charcot-Marie-Tooth disease and hysteria, to include internal medicine and its various subspecialties, such as rheumatology, pulmonology and geriatrics, as well as the specialties of orthopedics, pathology, psychiatry and psychology ${ }^{1,2,3,4}$. Between 1872 and 1893, Charcot was the most renowned neurologist in the world, and the La Salpêtrière Hospital the mecca of international neurology $y^{1,2,3,4,5,6,7}$. At the height of his career, internationally famous and 67 years old, Charcot died suddenly on August 16, 1893, of acute pulmonary edema secondary to myocardial infarction while on a trip to the French countryside with some of his assistants ${ }^{1,3,4,8}$. He had previously suffered various angina attacks due to atherosclerosis of the coronary arteries ${ }^{1,3,4,5}$. The aim of this article is to review the death of Professor Charcot, in Morvan, in the French countryside, his funeral and his burial in Montmartre cemetery in Paris.

\section{Charcot's Death}

Jean-Martin Charcot (Figure 1) had an unhealthy life. Short and obese, predominantly around the waist, with a short neck, he had poor personal hygiene, a voracious appetite and disturbed sleep cycles caused by intense intellectual activity stretching late into the night. He was a chronic heavy smoker, exhibited taciturn behavior and led a sedentary life li, $3,5,5,7$. He developed progressive intermittent episodes of precordial discomfort and anxiety suggestive of coronary insufficiency and, in 1890, during a dinner party at his house in Boulevard Saint Germain, Professor Potain, a famous Parisian clinician, confirmed a diagnosis of angina pectoris. The clinical picture indicated a potentially fatal outcome within two years ${ }^{1,3,4}$. Charcot also suffered from chronic lower back pain, and gait and posture disorders (flexed posture of the trunk and shuffling gait with marche à petit pas) suggestive of vascular Parkinsonism ${ }^{1,3,4,9}$. In August 1893, during a summer holiday, Charcot travelled with his disciples, Professors Debove and Straus, to Morvan, a rural lake district in Burgundy, southeast of Paris. On August 15, after quite an active day, Charcot and his two assistants, ate a Pantagruelian meal and retired to their rooms at the countryside inn, L'Auberge du Lac des

${ }^{1}$ Universidade Federal do Paraná, Hospital de Clínicas, Departamento de Clínica Médica, Serviço de Neurologia, Curitiba PR, Brasil;

${ }^{2}$ GeneralPractice, Brou, France.

Correspondence: Hélio A. G. Teive; Rua General Carneiro 1103/102, Centro, Curitiba, PR, 80060-150, Brasil. E-mail: hagteive@mps.com.br Conflict of interest: There is no conflict of interest to declare.

Received 06 August 2017; Accepted 08 August 2017. 
Settons (Figure 2). Charcot then wrote a letter to his wife, giving her details of the trip. However, at 3 am on August 16, the innkeeper's wife called Charcot's two assistants to the renowned physician's room. Charcot had developed sudden dyspnea, with intense perspiration, pallor, an anguished expression and coarse rales in his chest, and a diagnosis of acute pulmonary edema was made. His condition worsened, and he died that morning, at the age of 67, confirming the diagnosis of coronary artery insufficiency made by Professor Potain two years previously ${ }^{1,3,4,9}$.

\section{Charcot's Funeral}

Charcot's coffin was taken to Paris and placed in the chapel of the Salpêtrière Hospital ${ }^{1,3}$. The following day, the visitation was attended by countless patients, medical

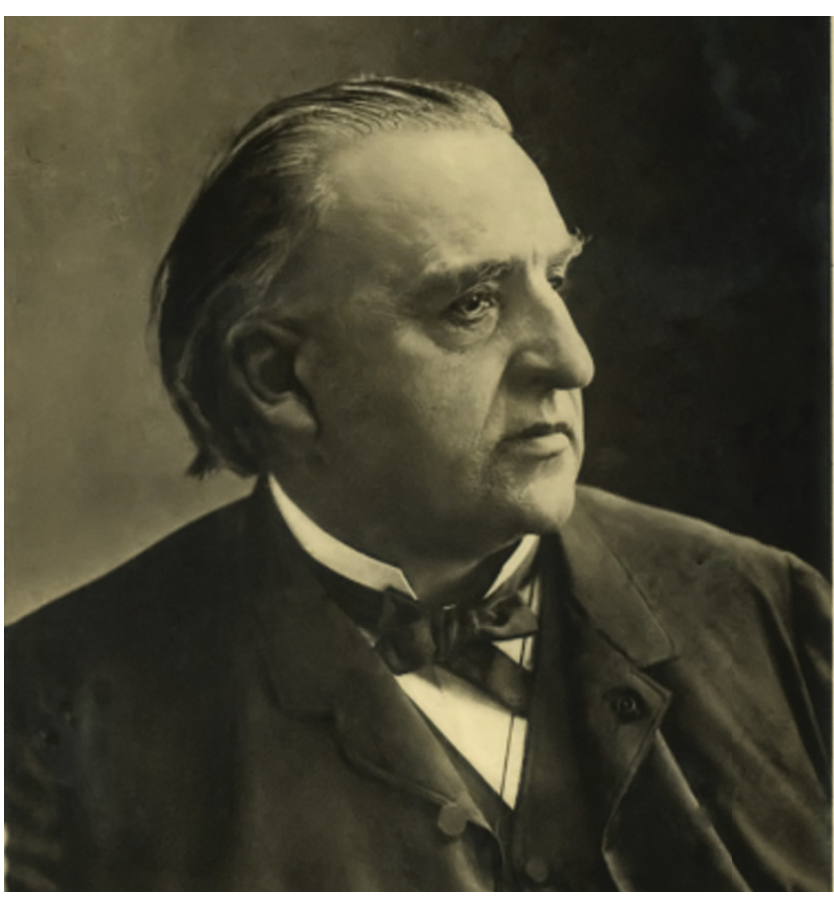

(From the private collection of the author - OW).

Figure 1. Professor Jean-Martin Charcot (1825-1893).

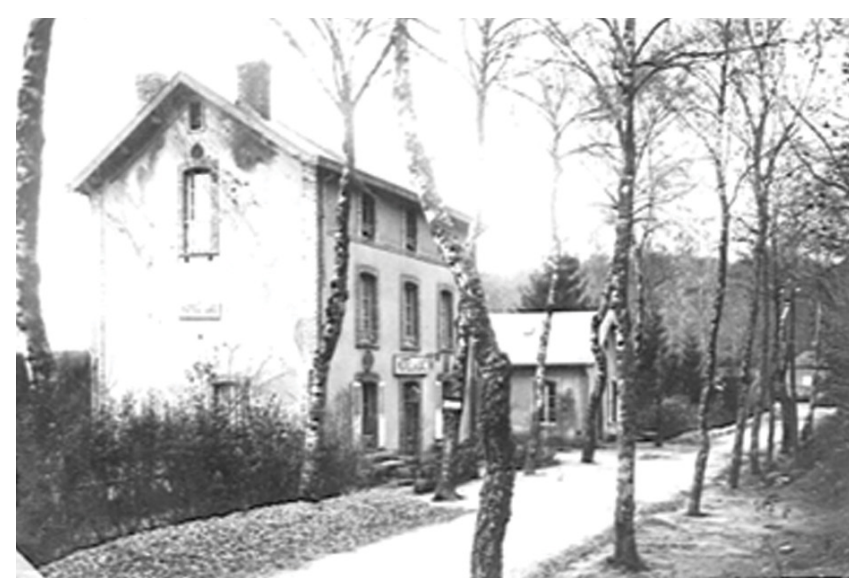

(From the private collection of the author - OW).

Figure 2. The house where Charcot died at the Lac des Settons. students, nurses, physicians, disciples, professors, artists, writers, members of the Parisian intelligentsia and leaders of Parisian, French and foreign medical societies, as well as prominent members of the government and Parisian, French, European and international society ${ }^{1,3}$. A simple funeral service was held at the Saint-Louis church of La Salpêtrière Hospital itself, without any speakers or religious manifestations, as the deceased had requested, but with military honors (Figure 3). Beethoven's Funeral March and St. Saens's Pie Jesu were played. After the ceremony, the coffin was taken to Montmartre cemetery for burial ${ }^{1,3}$.

\section{Charcot's Grave at Montmartre}

Charcot was buried in the family tomb in Montmartre cemetery (division 29, Chemin Troyon) in the south of Paris ${ }^{1,3}$ (Figure 4). His son, Jean-Baptiste Charcot, the world-famous Commander Charcot, was buried in the same place in $1936^{1,3}$. Charcot's death was felt around the world, with mentions in medical journals and newspapers and more than 70 eulogies published between 1893 and 1894 in France, various European countries and the USA. Important professors from many different countries, including Osler (USA), Freud (Austria), Jendrassik (Polonia), and Leyden, Erb, Strümpel and Mobius (Germany), published articles on Charcot $^{1,3}$, and in France, Féré, Joffroy, Gilles de la Tourette and Bourneville wrote obituaries for him. However, undoubtedly one of the most moving tributes was paid by Pierre Marie and Brissaud, who wrote an obituary in Revue Neurologique ${ }^{10}$ in September 1893 under the title "Nécrologie J.-M. Charcot". Following are some excerpts from this obituary:

"Professor Charcot is dead. The day after such a sudden catastrophe, we are stunned and are unable to pay appropriate tribute to such a master"10.

"But we must speak about the neurologist, or rather, the creator of neurology. Before him was darkness and chaos. With him, clarity and order"10.

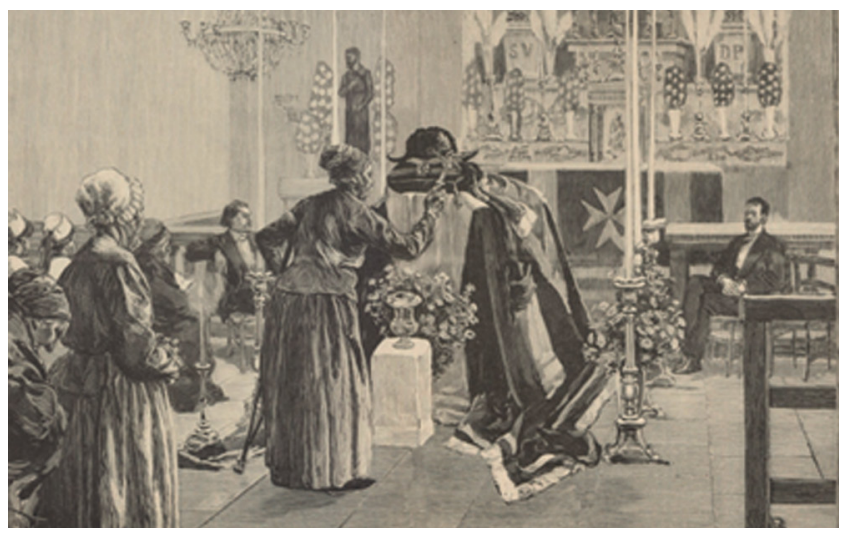

(From the private collection of the author - OW).

Figure 3. Charcot's funeral at the Saint-Louis church of La Salpêtrière hospital (in Le Monde Illustré, 06 aoüt, 1893). 
"But how can we simply list Charcot's works? That would be to describe the history of neurology in its entirety"10.

"His chair was the glory of our faculty and the jewel in his crown"10.

"Who among his pupils could forget him? Recognition is the sweetest sentiment"10.

After his death, Charcot's closest friends arranged for a statue of the famous master to be erected at the front of the
Salpêtrière Hospital (Figure 5). However, this was destroyed during the invasion of Paris by German troops in $1939^{1}$.

\section{CONCLUSION}

Professor Jean-Martin Charcot, a leading figure of international neurology in the $19^{\text {th }}$ century, whose teachings and discoveries are still of great importance, died on August 16, 1893, in the province of Morvan in the French countryside. His funeral took place in Paris at the Salpêtrière Hospital, and he was buried in Montmartre cemetery in Paris.

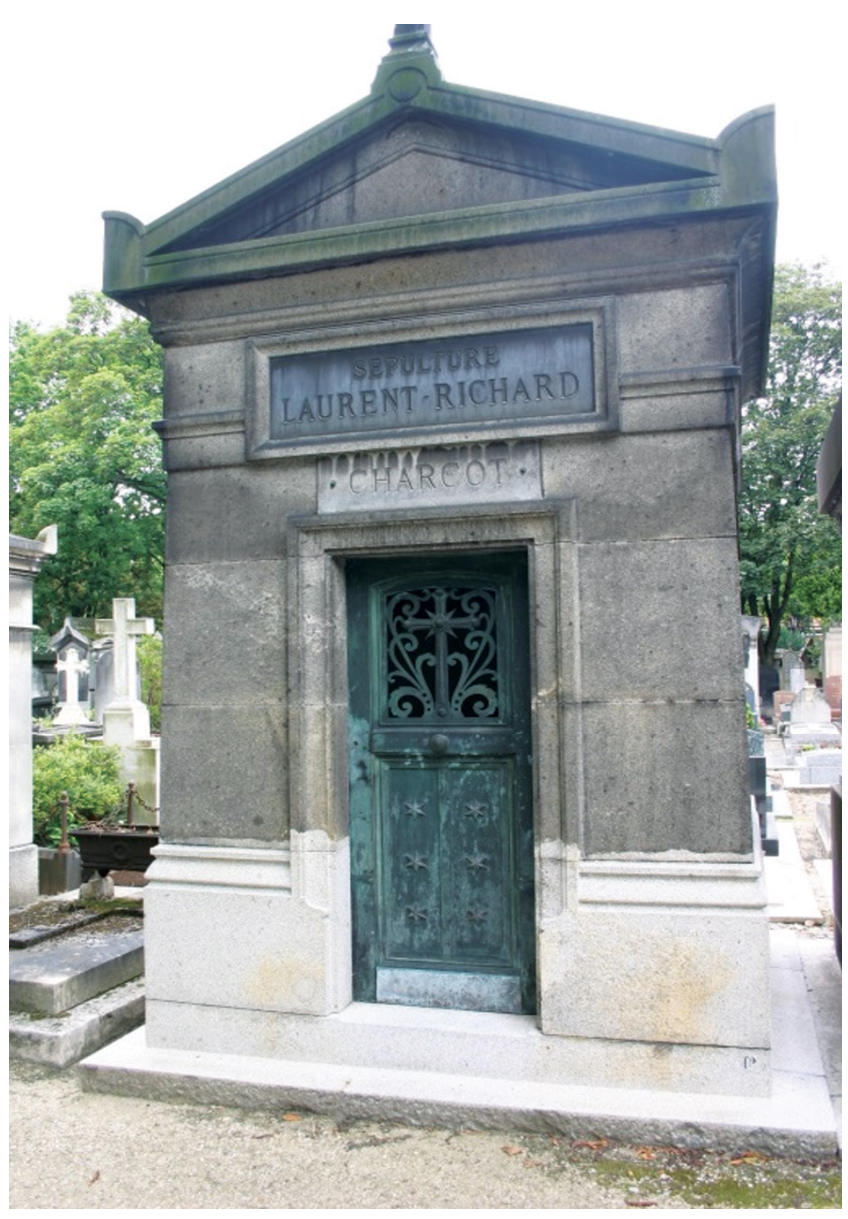

(Extracted from Google Images: HimetopWikidot, July, 02 ${ }^{\text {nd }}$, 2017). Figure 4. Charcot's grave at Montmartre cemetery.

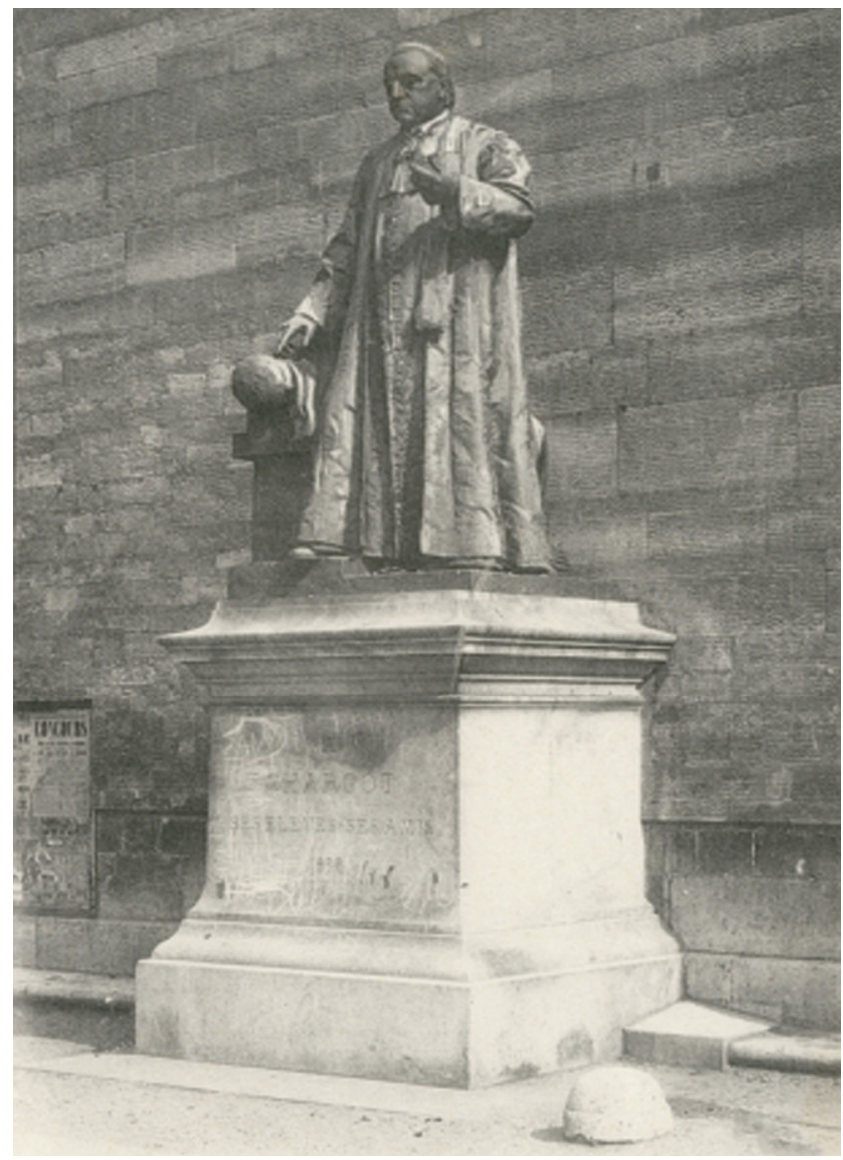

(From the private collection of the author - OW).

Figure 5. Charcot's statue in front of La Salpêtrière hospital, Paris, France.

\section{References}

1. Goetz CG, Bonduelle M, Gelfand T. Charcot: constructing neurology. New York: Oxford University Press; 1995

2. Teive HAG, Munhoz RP, Barbosa ER. Little-known scientific contributions of J-M Charcot. Clinics. 2007;62(3):211-4. https://doi.org/10.1590/S1807-59322007000300003

3. Guillain G.J-M. Charcot. 1825-1893: his life- his work. New York: Paul B. Hoeber; 1959.

4. Garrison FH. Charcot. Int Clinics. 1925; 35:244-72.

5. Bonduelle M. The intimate Charcot. Rev Neurol (Paris). 1994;150:524-8.
6. Guinon G. Charcot intime. Paris Medical. 1925;56:511-6.

7. Souques A. Charcot intime. La Presse Medicale. 1925;(42):693-8.

8. Goetz CG. The Salpêtrière in the wake of Charcot's death. Arch Neurol. 1988;45(4):444-7.

9. Teive HAG, Germiniani FMB, Munhoz RP. Charcot and vascular parkinsonism. Arq Neuropsiquiatr 2017;75(3):195-6. https://doi.org/10.1590/0004-282×20170007

10. Brissaud E, Marie P. Nécrologie:J.-M. Charcot. Rev Neurol. 1893;16:29-30 